\title{
Efektivitas Pelatihan Literasi Kitab untuk Mendukung Studi dan Penelitian Mahasiswa Fakultas Ushuluddin, Adab dan Humaniora di Perpustakaan IAIN Salatiga dan IAIN Purwokerto
}

\author{
Ifonilla Yenianti \\ IAIN Salatiga \\ ifonilla@gmail.com
}

\begin{abstract}
This research purpose to explore the level of effectiveness of Kitab literacy training program at IAIN Salatiga and IAIN Purwokerto. This research is a descriptive research with a quantitative approach. The sampling technique in this research was using nonprobability sampling-purposive sampling technique. The research instrument used a questionnaire while the data collection technique was by filling out a questionnaire. Data were analyzed using descriptive techniques with percentages. The results showed that the effectiveness level of the kitab literacy training at IAIN Salatiga was 82.15\% in the very effective category, as well as IAIN Purwokerto in the very effective category at $93.8 \%$. And has contributed to the achievement of the objectives of kitab literacy training at both IAIN Salatiga and IAIN Purwokerto. However, the training still needs some improvement, mainly in the development of training materials, improving the model of trainers in delivering the material, extending the time for training publication / socialization, increasing practice time, good training time management, providing representative training media technology and an adequate internet networks, and development of digital kitab information systems.
\end{abstract}

Keywords: Kitab Literacy, Information Literacy, Training Effectiveness 


\begin{abstract}
Abstrak
Penelitian ini bertujuan untuk mengetahui tingkat efektivitas pelatihan literasi kitab di IAIN Salatiga dan IAIN Purwokerto. Penelitian ini merupakan penelitian deskriptif dengan pendekatan kuantitatif. Teknik pengambilan sample pada penelitian ini menggunakan teknik non-probability sampling-purposive sampling. Instrumen penelitian menggunakan angket sedangkan teknik pengumpulan data dengan pengisian angket. Data dianalisis menggunakan teknik deskriptif dengan persentase. Hasil Penelitian menunjukkan tingkat efektivitas pelatihan literasi kitab di IAIN Salatiga sebesar $82.15 \%$ pada kategori sangat efektif, begitu juga IAIN Purwokerto pada kategori sangat efektif dan sebesar 93.8\%. Dan telah berkontribusi bagi pencapaian tujuan pelatihan literasi kitab baik di IAIN Salatiga maupun IAIN Purwokerto. Namun, tingkat pelatihan yang sudah dicapai masih perlu ditingkatkan, khususnya pada pengembangan materi pelatihan, memperbaiki model pelatih dalam menyampaikan materi, memperpanjang waktu publikasi/sosialisasi pelatihan, penambahan waktu praktek, manajemen waktu pelatihan yang baik, menyediakan teknologi media pelatihan yang representatif dan jaringan internet yang memadai, dan pengembangan sistem informasi kitab digital
\end{abstract}

Kata Kunci: Literasi Kitab, Literasi Informasi, Efektivitas Pelatihan

\title{
A. PENDAHULUAN
}

Perpustakaan IAIN Salatiga dan Perpustakaan IAIN Purwokerto adalah Perpustakaan yang mempunyai badan induk Institut Agama Islam Negeri di bawah pengawasan Dirjen Perguruan Tinggi Keagamaan Islam Negeri (PTKIN), Kementerian Agama RI. Sebagai Perpustakaan Perguruan Tinggi Keagamaan Islam Negeri, perpustakaan diharapkan mampu memenuhi kebutuhan koleksi bagi civitas akademik kampus yang terdiri dari dosen, mahasiswa, peneliti, karyawan dan pemustaka umum. Perpustakaan sebagai unit pelaksana teknis (UPT) juga diharapkan berperan dalam menguatkan Tri Dharma Perguruan Tinggi yaitu pendidikan, pengajaran dan pengabdian masyarakat.

Perpustakaan PTKIN bisa dikategorikan jenis perpustakaan khusus, terlihat dari koleksi yang dimiliki yaitu mayoritas merupakan buku-buku keislaman, sedangkan koleksi yang lain adalah merupakan koleksi penunjang 
saja. IAIN Salatiga dan IAIN Purwokerto sebagai perpustakaan PTKIN sudah barang tentu harus memaksimalkan pengadaan koleksi keislaman dan referensi kitab-kitab sebagai kekuatan koleksi di PTKIN.

Pemenuhan kebutuhan koleksi keislaman pemustaka harus korelatif dengan keterpakaian koleksi yang dimiliki perpustakaan. Jika dilihat dari keterpakaian koleksi yang ada di perpustakaan, maka koleksi buku di rak sirkulasi lebih diminati oleh pemustaka ketimbang koleksi di rak referensi. Walaupun pada dasarnya koleksi referensi hanya di baca di tempat atau sebagai buku rujukan saja, tetapi tetap harus dilihat tingkat keterpakaiannya sebagai buku rujukan.

Koleksi referensi kitab khususnya yang berbahasa Arab bukan hanya buku yang dijajarkan tanpa ada pemakainya. Disinilah peran pustakawan referensi untuk bisa mengenalkan berbagai jenis kitab berbahasa Arab maupun kitab yang sudah diterjemahkan. Perpustakaan IAIN Salatiga menggagas pelatihan literasi kitab sebagai jembatan untuk meningkatkan keterpakaian referensi kitab-kitab seperti berbagai jenis kitab Tafsir, Hadist, Ushul Fiqh, Kamus Fiqh, ensiklopedia Al-Qur’an dan lain-lain.

Trobosan baru pelatihan literasi kitab di Perpustakaan IAIN Salatiga sebagai solusi dari kegelisahan pustakawan referensi dalam melayankan koleksi referensi Islam yang mayoritas berbahasa Arab dan dalam bentuk berjilid-jilid. Tidak dipungkiri kendala bahasa menjadi awal dari sepinya pengguna koleksi referensi Islam ini baik dalam bentuk buku maupun digital. Maka di tahun 2016 Perpustakaan mengadakan Pelatihan literasi kitab secara gratis kepada seluruh pemustaka. Penawaran pelatihan literasi kitab dibuka secara umum untuk semua pemustaka dan secara khusus untuk mahasiswa Fakultas Ushuluddin, Adab dan Humaniora (FUAH).

Pelatihan literasi kitab diberikan ini dilayankan kepada seluruh pemustaka, terkhusus dilayankan untuk mahasiswa FUAH yang membutuhkan berbagai ketrampilan penelusuran kitab-kitab referensi sebagai pendukung studi dan penelitiannya.

Begitu juga Perpustakaan IAIN Purwokerto yang memiliki kesamaan koleksi pada koleksi referensi kitab-kitab. Perpustakaan memilih berlangganan 
Bookless untuk menjembatani keterpakaian kitab-kitab yang ada di rak referensi. Pustakawan referensi telah memberikan pelatihan literasi kitab berupa konsultasi penggunaan Bookless baik individu maupun kelompok. Pelatihan Literasi Kitab penggunaan Bookless di IAIN Purwokerto tercatat sejak tanggal 10 Februari 2016, dimana perpustakaan IAIN Purwokerto telah menggelar Bookless Lauching.

Pelatihan literasi kitab Bookless dilakukan dengan 2 cara yaitu pelatihan secara individu di ruang referensi dan secara kelompok yaitu pada kegiatan user education mahasiswa baru.

Bookless adalah aplikasi penelusuran kitab-kitab yang dapat diakses dari komputer yang disediakan di perpustakaan IAIN Purwokerto, smartphone, tablet dan notebook pribadi dengan fasilitas wifi di alamat http:// bookless.id. Bookless di IAIN Purwokerto mempunyai menu antara lain; Ensiklopedi Al Qur’an; Ensiklopedi Hadis; Ensiklopedi Siroh; Ensiklopedi Fikih; Ensiklopedi Umum; Asmaul Husna ; E-Book; Kamus.

Adapun pelatihan literasi kitab bookless ini dilayankan kepada seluruh pemustaka, terkhusus dilayankan untuk mahasiswa FUAH yang membutuhkan berbagai ketrampilan penelusuran kitab-kitab referensi sebagai pendukung studi dan penelitiannya.

Evaluasi terhadap efektivitas pelatihan literasi kitab pada mahasiswa Fakultas Ushuluddin, Adab dan Humaniora (FUAH) ini sangat penting dilakukan untuk perbaikan kualitas pelatihan, metode pelatihan dan hasil pelatihan, sehingga diharapkan melalui pelatihan literasi kitab ini mahasiwa FUAH di IAIN Salatiga dan IAIN Purwokerto dapat menyelesaikan tugastugas kuliah dengan baik dan dapat menunjang referensi dalam penelitian ataupun penyusunan karya ilmiah.

\section{B. TINJAUAN LITERATUR}

\section{1) Evaluasi Efektivitas Program Pelatihan Kirkpatric}

Efektifitas merupakan "hubungan antara output dengan tujuan, semakin besar kontribusi (sumbangan) output terhadap pencapaian tujuan, 
maka semakin efektif organisasi, program atau kegiatan" (Mahmudi, 2005). Dengan kata lain, efektivitas merupakan tingkat keberhasilan dalam pencapaian tujuan.

Menurut Kirkpatrick \& Kirkpatrick (2007) efektivitas suatu program memiliki sepuluh persyaratan yaitu:

1) Melandaskan program pada kebutuhan peserta.

2) Menentukan tujuan penelitian

3) Menjadwalkan (pelatihan) pada waktu yang tepat

4) Mempertimbangkan tempat

5) Mengundang peserta yang tepat

6) Memilih pelatih yang efektif

7) Menggunakan metode dan alat pembelajaran yang tepat

8) Memastikan tujuan pelatihan tercapai

9) Memuaskan peserta

10) Mengevaluasi kegiatan pelatihan

Dalam konteks penelitian ini, maka efektivitas program pelatihan yang dimaksud adalah tingkat keberhasilan dalam menyelenggarakan kegiatan program pelatihan literasi kitab di perpustakaan IAIN Salatiga dan di Perpustakaan IAIN Purwokerto.

Setiap kegiatan program pelatihan memiliki tujuan yang diinginkan. Untuk mengetahui tingkat keberhasilan program pelatikan literasi kitab diperlukan kegiatan evaluasi program. Salah satu evaluasi program pelatihan dapat dilakukan dengan pendekatan model Kirkpatrick. Dalam pendekatan ini terdapat empat model tingkatan evaluasi yaitu: reaksi (reaction), pembelajaran (learning), perilaku (behavior) dan perubahan organisasi (result). (Kirkpatric. 2007). 


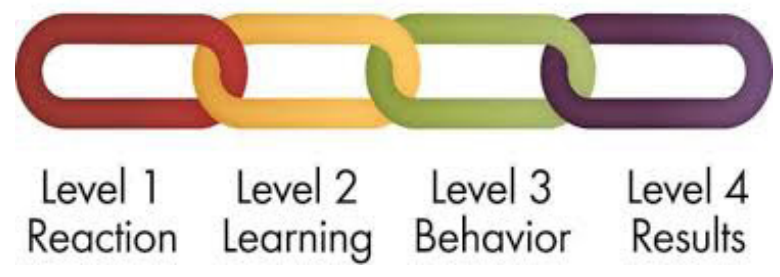

\section{Gambar 1 Model evaluasi pelatihan Kirkpatrik}

1) Tingkat 1. Reaksi peserta (reaction)

Pada tingkatan 1 adalah untuk mengetahui sejauh mana reaksi peserta merasa senang dengan program pelatihan yang diselenggarakan.

2) Tingkat 2. Belajar (learning)

Pada tingkat 2 adalah untuk mengetahui sejauh mana peserta membutuhkan pengetahuan, keterampilan, sikap, kepercayaan diri, dan komitmen yang didasarkan pada partisipasi peserta dalam kegiatan pelatihan tersebut.

3) Tingkat 3. Perubahan Perilaku (behavior)

Pada tingkat 3 adalah untuk mengetahui peserta menerapkan apa yang mereka pelajari dalam mengikuti program pelatihan tersebut.

4) Tingkat 4. Hasil Perubahan Organisasi (result)

Tingkat 4 adalah untuk mengetahui sejauh mana hasil yang ditargetkan terlaksana. Akibat dari hasil kegiatan program pelatihan dan penguatan selanjutnya. Hasil perubahan ini akan berdampak pada perubahan organisasi.

\section{2) Perpustakaan Perguruan Tinggi}

Menurut Sulistyo-Basuki perpustakaan perguruan tinggi adalah perpustakaan yang terdapat pada perguruan tinggi, badan bawahannya, maupun lembaga yang berafiliasi dengan perguruan tinggi tersebut, dengan tujuan utama membantu perguruan tinggi mencapai tujuannnya. (SulistyoBasuki, 1993. Hal.51).

Begitu juga menurut Mulyani. A. Nurhadi menyebutkan bahwa perpustakaan perguruan tinggi adalah perpustakaan yang diselenggarakan 
oleh lembaga perguruan tinggi untuk menunjang tridarma perguruan tinggi. (Mulyani A. Nurhadi, 1983. Hal.9)

Pendapat keduanya dikuatkan oleh Soeatminah, yang mengatakan bahwa perpustakaan perguruan tinggi adalah suatu unsur penunjang yang merupakan perangkat kelengkapan di bidang pendidikan, penelitian dan pengabdian pada masyarkat. (Soeatminah, 1992. Hal. 40)

Dan lebih terperinci lagi, menurut Mastini Hardjoprakoso dalam Urias Ibo mengatakan bahwa perpustakaan perguruan tinggi adalah:

1. Merupakan perpustakaan yang diselenggarakan di lingkungan universitas/ institute dan lembaga perguruan tinggi lainnya;

2. Berstatus sebagai unit teknis (UPT) di bawah pembantu rektor bidang akademis;

3. Mempunyai tugas sebagai perpustakaan pusat untuk kegiatan pendidikan, penelitian, dan pengabdian masyarakat dan bagian integral dari sistem pendidikan di perguruan tinggi;

4. Tugas dan fungsi serta tata kerja perpustakaan perguruan tinggi diatur dengan keputusan menteri pendidikan nasional. (Urias Ibo, 2008.Hal. 14)

Sedangkan Rachman Hermawan dan Zulfikar Zein mengungkapkan lebih sederhana bahwa "perpustakaan perguruan tinggi adalah perpustakaan yang terdapat di lingkungan lembaga perguruan tinggi seperti universitas, institut, sekolah tinggi, akademi dan lembaga perguruan tinggi lainnya”. (Rachman Hermawan dan Zulfikar Zein, 2006. Hal.33).

IAIN Salatiga dan IAIN Purwokerto adalah institusi pendidikan dibawah payung Perguruan Tinggi Keagamaan Islam Negeri (PTKIN) Kementerian Agama RI. Adapun tugas besar perguruan tinggi keagamaan Islam di Indonesia antara lain: 1) Mencetak sarjana yang berkualitas, bermutu dan berakhlak, ini dimaksudkan bahwa lulusan PTKIN tidak hanya pintar namun juga mampu bersaing dengan bangsa lain dalam bingkai keIslaman. 2) Mempertahankan dan merawat Islam Indonesia yakni Islam yang damaitoleran-demokratis terhadap keberagaman yang ada di bangsa Indonesia. Dalam hal ini lulusan PTKIN harus mampu menangkal paham-paham 
agama yang ekstrim. Selanjutnya, 3) Mentransformasi atau melakukan objektivikasi pengetahuan keagamaan menjadi perilaku keagamaan. Tidak hanya mencetak sarjana yang tahu, tetapi bisa dilakukan dalam praktek sehari-hari di lingkup sosial dan masyarakat. Dan di tahun 2020 ini total PTKI ada 895 lembaga dengan perincian 59 PTKIN dan 837 PTKIS. (http:// diktis.kemenag.go.id)

\section{3) Literasi Informasi}

Secara Etimologis, literasi berasal dari bahasa latin littera yang memiliki pengertian yaitu sistem tulisan yang menyertainya. Literasi adalah hak asasi manusia yang fundamental dan pondasi untuk belajar sepanjang hayat. Hal ini penting sepenuhnya untuk pembangunan sosial dan manusia dalam kemampuannya untuk mengubah kehidupan. (Malawi, 2017. Hal. 6)

Sedangkan Hartono mendefinisikan literasi sebagai kemampuan untuk menggunakan bahasa dan gambar dalam bentuk yang kaya dan beragam untuk membaca, menulis, mendengarkan, berbicara, melihat, menyajikan, dan berfikir kritis tentang ide-ide. Literasi merupakan proses yang melibatkan pembangunan pengetahuan baru dan pemahanan yang lebih dalam. (Hartono, 2016. Hal. 242)

Konsep literasi Informasi pertama kali dikenalkan oleh Paul Zurkowski pada tahun 1974. Zurkoswsky berpendapat bahwa seorang yang terlatih dalam menggunakan sumber-sumber informasi dalam menyelesaikan tugas mereka disebut orang yang melek informasi karena mereka telah belajar teknik menggunakan informasi dengan baik dan keterampilan dalam menggunakan alat informasi. (Hendra Wicaksono, 2016. Hal. 23)

Menurut American Library Association (ALA) mendefinisikan literasi informasi (Information Literacy) adalah serangkaian kemampuan yang dibutuhkan seseorang untuk menyadari kapan informasi dibutuhkan dan memiliki kemampuan untuk menemukan, mengevaluasi dan menggunakan informasi yang dibutuhkan secara efektif. (Abidin Y., 2018. Hal. 1)

The UK's Chartered Institute of Library and Information Professional (CILIP) mendefinisikan bahwa literasi informasi adalah mengetahui kapan 
dan kenapa kita membutuhkan informasi, mengetahui dimana kita dapat menemukan dan bagaimana mengevaluasinya, serta dapat menggunakan dan mengkomunikasikannya sesuai etka. (Amstrong, 2005).

Sumber-sumber referensi Islam seperti kitab-kitab Tafsir, Hadis, Fiqh, Ulumul Qur'an dan lain sebagainya merupakan koleksi unggulan sebuah Perguruan Tinggi Keagamaan Islam Negeri (PTKIN). Untuk mengenalkan keunggulan koleksi PTKIN, Perpustakaan IAIN Salatiga dan Perpustakaan IAIN Purwokerto telah memberikan beberapa pelatihan literasi informasi kepada para pemustaka. Salah satu dari kegiatan pelatihan literasi informasinya adalah pelatihan literasi kitab. Hal ini bertujuan agar mahasiswa terlatih dalam menggunakan sumber-sumber informasi berupa kitab-kitab referensi yang tesedia di perpustakaan untuk menyelesaikan tugas perkuliahan dan penelitiannya.

\section{4) Koleksi Referensi Kitab Perguruan Tinggi Islam}

Sulityo Basuki menyatakan bahwa perpustakaan perguruan tinggi umumnya bertujuan untuk: (Sulistyo Basuki, 1993)

1. Memenuhi keperluan informasi masyarakat perguruan tinggi, lazimnya staf mengajar dan mahasiswa. Sering pula mencakup pula tenaga administrasi perguruan tinggi.

2. Menyediakan bahan pustaka rujukan (referens) pada semua tingkat akademis, artinya mulai dari mahasiswa tahun pertama hingga ke mahasiswa program pasca sarjana dan pengajar.

3. Menyediakan ruang belajar untuk pemakai perpustakaan.

4. Menyediakan jasa peminjaman yang tepat guna bagi berbagai jenis pemakai.

5. Menyediakan jasa informasi aktif yang tidak saja terbatas pada lingkungan perguruan tinggi tetapi juga lembaga industri lokal.

Menurut Standar Nasional Indonesia (SNI) Perpustakaan Perguruan Tinggi, Materi Referensi dari perpustakaan adalah: "Buku yang disusun untuk memberikan informasi berbagai macam hal dan dimaksudkan sebagai 
acuan bukan untuk dibaca secara keseluruhan, seperti atlas, bibliografi, buku tahunan, ensiklopedi, direktori, indeks, kamus." (SNI 7330:2009 Hal. 2)

Untuk Perguruan Tinggi Islam, kitab-kitab hukum Islam dan berbagai macam kitab hadits dan tafsir dapat dimasukkan menjadi bahan materi dari koleksi referensi perpustakaan. Karena karakteristik dari kitab-kitab tersebut yaitu menyediakan informasi mengenai berbagai macam hal yang dijadikan sebagai pedoman atau acuan namun tidak perlu dibaca secara keseluruhan. (Lalu Agus Satriawan, 2015. Hal.3).

Berbagai jenis kitab hadis, tafsir, fiqh, ushul fiqh, ulumul qur'an dimasukkan dalam koleksi referensi Islam di Perpustakaan IAIN Salatiga dan IAIN Purwokerto. Jenis koleksi inilah sebagai keunggulan perpustakaan perguruan tinggi Islam dengan perpustakaan tinggi umum lainnya.

\section{METODOLOGI PENELITIAN}

Penelitian ini menggunakan metode kuantitatif dengan pendekatan model Krirkpatrick. Model Krikpatrick ini digunakan untuk mengevaluasi efektivitas pelatihan literasi kitab yaitu pada reaksi peserta dan proses pelatihan peserta.

Peserta pelatihan literasi kitab ini adalah mahasiswa Fakultas Ushuluddin, Adab dan Humaniora (FUAH) IAIN Salatiga dan IAIN Purwokerto. Jumlah peserta dari IAIN Salatiga sebanyak 28 peserta yang terdiri dari 11 laki-laki dan 17 perempuan. Namun jumlah peserta yang memberikan jawaban pada pre-post test sejumlah 14 peserta. Dan jumlah peserta dari mahasiswa FUAH IAIN Purwokerto sebanyak 36 peserta terdiri dari 15 laki-laki dan 21 perempuan. Namun julah peserta yang mengisi prepost test sebanyak 16 peserta. Kemudian seluruh peserta pelatihan dijadikan sampel dalam penelitian.

Menurut Kirkpatrick (dalam Ramadhon, 45) evaluasi terhadap efektivitas program pelatihan mencakup empat level evaluasi, yaitu 1) reaction level, 2) learning level, 3) behavior level, 4) result level. Melalui metode ini diharapkan dapat memahami tingkat efektivitas program pelatihan literasi 
kitab dalam rangka mendukung upaya peningkatan kualitas studi dan penelitian mahasiswa IAIN Salatiga dan IAIN Purwokerto.

Teknik pengumpulan data pada penelitian ini adalah:

1) Evaluasi tahapan reaksi peserta yaitu evaluasi peserta dan evaluasi kualitas tentang efektivitas program pelatihan literasi kitab dilakukan dengan menyebarkan kuesioner kepada:

a. Seluruh peserta pelatihan berupa lembar evaluasi peserta

b. Seorang pengamat/observer pelatihan berupa lembar evaluasi kualitas

2) Evaluasi tahapan kedua berupa pre-post test, yaitu memberikan tes awal sebelum pelatihan dan tes akhir setelah pelatihan.Untuk tahap evaluasi pre-post test terkait materi literasi kitab menyesuaikan dengan kegiatan literasi kitab yang telah berjalan di masing-masing institusi baik di Perpustakaan IAIN Salatiga maupun Perpustakaan IAIN Purwokerto.

3) Evaluasi tahapan proses pelatihan untuk mendapatkan data sekunder. Selanjutnya untuk mengetahui relevansi dan efektivitas pelatihan literasi kitab peneliti mensyarakatkan nilai "sangat baik" dan "baik" lebih besar atau sama dengan $80 \%$

\section{PEMBAHASAN}

\section{Analisis Deskripsi Butir Soal Pre-Post Test Pelatihan Literasi Kitab}

a) IAIN Salatiga

Pre-test dan post-test menjadi salah satu instrument penting dalam pelaksanaan pelatihan literasi kitab. Pre-test dan Post-test berisi 15 butir pertanyaan yang sama. Pre-test diberikan kepada peserta sebelum pelaksanaan acara pelatihan literasi kitab, sedangkan untuk post-test diberikan kepada peserta setelah peserta mengikuti pelatihan literasi kitab. Pertanyaanpertanyaan diajukan dengan tujuan untuk mengetahui tingkat pemahaman peserta pelatihan terhadap materi yang disampaikan oleh narasumber acara berlangsung. Tabel dibawah ini adalah jawaban dari setiap butir pertanyaan yang dijawab oleh peserta pelatihan literasi kitab: 


\section{Tabel. 1 Hasil Pre-test dan Post-test IAIN Salatiga}

\begin{tabular}{clcc}
\hline No. & \multicolumn{1}{c}{ Butir Pertanyaan } & Pre-Test & Post-Test \\
\hline 1. & Hadis sahih & $35.7 \%$ & $42.9 \%$ \\
\hline 2. & Hadis hasan & $85.7 \%$ & $71.4 \%$ \\
\hline 3. & Hadis daif & $50 \%$ & $42.9 \%$ \\
\hline 4. & Hadis berdasar sumber beritanya & $92.9 \%$ & $71.4 \%$ \\
\hline 5. & Mutawatir & $78.6 \%$ & $85.7 \%$ \\
\hline 6. & Ahad & $85.7 \%$ & $92.9 \%$ \\
\hline 7. & Hadis sahih yang tidak bisa diamalkan & $42.9 \%$ & $57.1 \%$ \\
\hline 8. & Hadis daif yang bisa diamalkan & $28.6 \%$ & $14.3 \%$ \\
\hline 9. & Hadis yang wajib diamalkan & $21.4 \%$ & $14.3 \%$ \\
\hline 10. & Indikator sanad yang tersambung & $71.4 \%$ & $71.4 \%$ \\
\hline 11. & Sanad yang seolah tersambung namun sebenarnya & $78.6 \%$ & $78.6 \%$ \\
& terputus & & \\
\hline 12. & Pernyataan penilaian adil & $71.4 \%$ & $64.3 \%$ \\
\hline 13. & Pernyataan penilaian dabit & $78.6 \%$ & $78.6 \%$ \\
\hline 14. & Takhrij & $92.9 \%$ & $85.7 \%$ \\
\hline 15. & 'tibar & $100 \%$ & $71.4 \%$ \\
\hline
\end{tabular}

Berdasarkan persentase di atas diketahui bahwa secara umum peserta memahami soal-soal yang akan dibahas pada pelatihan literasi kitab. Hal tersebut bsia dilihat dari 15 butir pertanyaan, hanya 4 butir soal saja yang mendapatkan persentase di bawah $60 \%$ yaitu pada butir soal hadis sahih, hadis daif, hadis daif yang bisa diamalkan, dan hadis yang wajib diamalkan. Sisanya 11 pertanyaan berhasil dijawab peserta dengan persentase diatas $60 \%$ bahkan pada butir soal I'tibar semua peserta berhasil memperoleh persentase $100 \%$ yang menunjukan pada butir soal takhrij, semua peserta berhasil menjawab dengan benar.

Kemudian hasil post-test menunjukkan bahwa secara keseluruhan peserta pelatihan literasi kitab IAIN Salatiga lebih banyak mengalami penurunan pemahaman terhadap materi yang disampaikan. Hal itu bisa dilihat dari 15 butir soal, hanya 4 butir soal yang mengalami kenaikan 
persentase, 3 butir soal tidak mengalami perubahan persentase, dan 8 butir soal justru mengalami penurunan persentase.

Data hasil pre-test dan post-test peserta pelatihan literasi kitab kemudian dilakukan uji-t untuk melihat adanya perubahan pengetahuan peserta literasi kitab di IAIN Salatiga dan IAIN Purwokerto setelah mengikuti pelatihan. Adapun hasil analisis statistik bisa dilihat pada tabel berikut.

\begin{tabular}{ccccccc}
\hline & \multicolumn{2}{c}{ All: 14 dari 14} & \multicolumn{2}{c}{ L: 4} & \multicolumn{2}{c}{ P: 10} \\
\cline { 2 - 6 } Pre \& Post Test & Pre & Post & Pre & Post & Pre & Post \\
\hline Mean & 67,62 & 58,57 & 68,33 & 58,33 & 67,33 & 58,67 \\
\hline Stdev & 8,62 & 19,94 & 10,00 & 21,34 & 8,58 & 20,56 \\
\hline T-Test & $-0,72$ & $-0,22$ & $-0,19$ \\
\hline Ada Perubahan & ada & ada & ada \\
\hline efect size & $-0,52$ & \multicolumn{2}{c}{$-0,78$} & $-0,45$ \\
\hline efektifitas & sedang & sedang & kecil \\
\hline
\end{tabular}

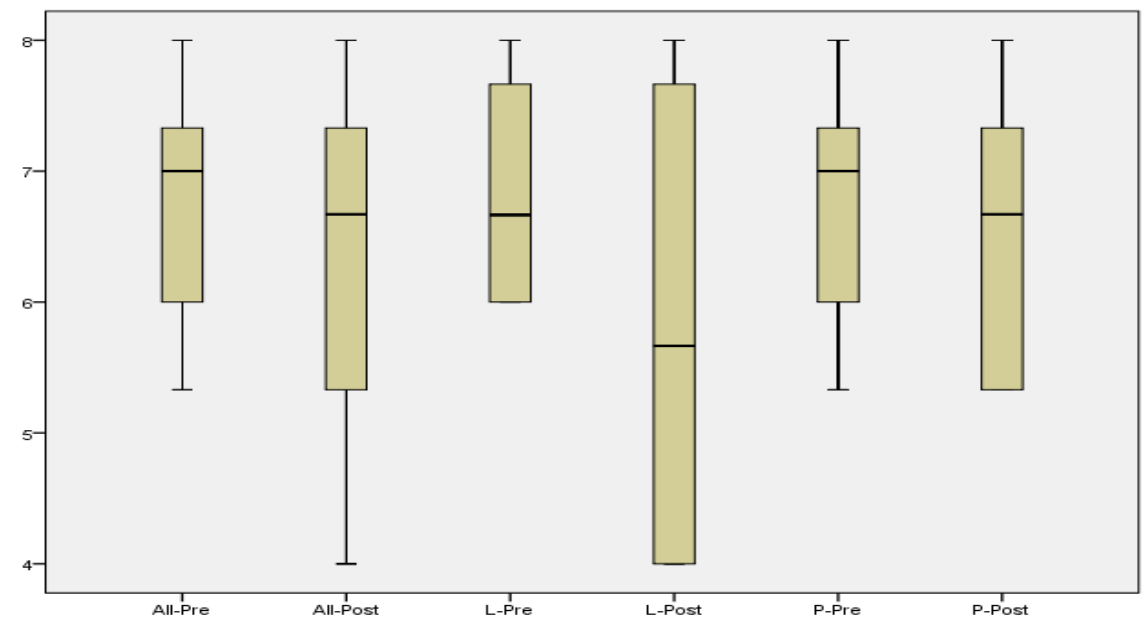

Diagram Hasil Uji t Terhadap Hasil Pre-Post test IAIN Salatiga

Berdasarkan tabel olah statistik di atas, dapat diketahui bahwa:

1) Rata-rata nilai pre-test dan post-test seluruh peserta pelatihan literasi kitab IAIN Salatiga menunjukan penurunan. Nilai rata-rata pre-test lebih tinggi 
(67.62) dibandingkan dengan nilai post-test (58.57). Nilai rata-rata pretest peserta laki-laki lebih tinggi (68.33) daripada nilai rata-rata pre-test peserta perempuan (67.33). Namun setelah dilakukan pelatihan, rata-rata post-test peserta perempuan yang lebih tinggi (58.67) daripada rata-rata nilai post-test peserta laki-laki (58.33).

2) Pengetahuan peserta literasi kitab IAIN Salatiga secara umum mengalami penurunan sebesar -9.05 poin, peserta laki-laki mengalami penurunan sebesar -10 poin, sedangkan peserta perempuan mengalami penurunan sebesar -8.66 poin.

3) Dalam uji t menunjukkan bahwa secara keseluruhan peserta mengalami perubahan (negatif) menurun dengan nilai $t$-test -0.72 . Peserta laki-laki secara umum mengalami perubahan dengan nilai $t$-test sebesar -0.22 dan peserta perempuan secara umum mengalami perubahan menurun dengan nilai t-test sebesar -0.19 .

4) Tingkat efektifitas pada pre-post test yang telah dilakukan memberikan dampak perubahan menurun tingkat sedang dengan nilai efect size sebesar -0.52. Peserta laki-laki mengalami perubahan menurun tingkat sedang dengan nilai efect size -0.78 lebih besar dibandingkan dengan nilai efect size peserta perempuan sebesar -0.45 .

\section{b) IAIN Purwokerto}

Tabel dibawah ini adalah jawaban dari setiap butir pertanyaan yang dijawab oleh peserta pelatihan literasi kitab IAIN Purwokerto:

\section{Tabel. 2 Hasil Pre-test dan Post-test IAIN Purwokerto}

\begin{tabular}{clcc}
\hline No. & \multicolumn{1}{c}{ Butir Pertanyaan } & Pre-Test & Post-Test \\
\hline 1. & Sosialisasi bookless & $75 \%$ & $75 \%$ \\
\hline 2. & Definisi bookless & $50 \%$ & $62.5 \%$ \\
\hline 3. & Cara penggunaan bookless & $25 \%$ & $87.5 \%$ \\
\hline 4. & Sistem informasi & $100 \%$ & $81.3 \%$ \\
\hline 5. & Kemudahan akses & $75 \%$ & $100 \%$ \\
\hline
\end{tabular}




\begin{tabular}{clcc}
\hline No. & \multicolumn{1}{c}{ Butir Pertanyaan } & Pre-Test & Post-Test \\
\hline 6. & Penelusuran qur'an & $87.5 \%$ & $93.8 \%$ \\
\hline 7. & Penelusuran hadits & $87.5 \%$ & $93.8 \%$ \\
\hline 8. & Penelusuran fiqih & $100 \%$ & $87.5 \%$ \\
\hline 9. & Pengetahuan sejarah & $81.3 \%$ & $81.3 \%$ \\
\hline 10. & Penelusuran buku-buku digital & $37.5 \%$ & $43.8 \%$ \\
\hline 11. & Penggunaanya untuk sumber kutipan & $100 \%$ & $93.8 \%$ \\
\hline 12. & Validitas informasi & $75 \%$ & $87.5 \%$ \\
\hline 13. & $\begin{array}{l}\text { Manfaat belajar literasi kitab digital dengan } \\
\text { bookless }\end{array}$ & $93.8 \%$ & $93.8 \%$ \\
\hline 14. & $\begin{array}{l}\text { Signifikansi dengan pengembangan pengetahuan } \\
\text { dan wawasan intelektual mahasiswa }\end{array}$ & $87.5 \%$ & $75 \%$ \\
\hline 15. & Pemanfaatan berkelanjutan oleh mahasiswa & $56.3 \%$ & $93.8 \%$ \\
\hline
\end{tabular}

Berdasarkan persentase di atas diketahui secara umum peserta memahami soal-soal yang akan dibahas pada pelatihan literasi kita. Hal tersebut bisa dilihat dari 15 butir pertanyaan, hanya 4 butir soal saja yang mendapatkan persentase di bawah 60\% yaitu pada butir soal Definisi bookless, Cara penggunaan bookless , Penelusuran buku-buku digital, dan Pemanfaatan berkelanjutan oleh mahasiswa. Sisanya 11 pertanyaan berhasil dijawab peserta dengan persentase diatas $60 \%$ bahkan pada butir soal sistem informasi, penelusuran fiqih, dan penggunaanya untuk sumber kutipan semua peserta berhasil memperoleh persentase $100 \%$ yang menunjukan pada butir soal Penggunaanya untuk sumber kutipan, semua peserta berhasil menjawab dengan benar.

Kemudian hasil post-test, secara keseluruhan peserta pelatihan literasi kitab IAIN Purwokerto lebih banyak mengalami peningkatan pemahaman terhadap materi yang disampaikan. Hal itu bisa dilihat dari 15 butir soal, 8 butir soal mengalami kenaikan persentase, 3 butir soal tidak mengalami perubahan persentase, dan hanya 4 butir soal yang mengalami penurunan persentase.

Adapun Hasil uji t terhadap hasil pre-post test di IAIN Purwokerto adalah sebagaimana tabel berikut: 


\begin{tabular}{ccccccc}
\hline \multirow{2}{*}{$\begin{array}{c}\text { Pre \& Post } \\
\text { Test }\end{array}$} & \multicolumn{2}{c}{ All: 16 dari 16} & \multicolumn{2}{c}{ L: 4} & \multicolumn{2}{c}{ P: 12} \\
\cline { 2 - 7 } Pre & Post & Pre & Post & Pre & Post \\
\hline Mean & 75,42 & 81,67 & 69,33 & 73,33 & 78,18 & 85,45 \\
\hline Stdev & 11,08 & 15,49 & 3,65 & 17,00 & 12,33 & 13,93 \\
\hline T-Test & \multicolumn{2}{c}{0,11} & \multicolumn{2}{c}{0,66} & 0,11 \\
\hline $\begin{array}{c}\text { Ada } \\
\text { Perubahan }\end{array}$ & \multicolumn{2}{c}{ ada } & \multicolumn{2}{c}{ ada } & \multicolumn{2}{c}{ ada } \\
\hline efect size & 0,42 & 0,21 & \multicolumn{2}{c}{0,53} \\
\hline efektifitas & Kecil & kecil & sedang \\
\hline
\end{tabular}

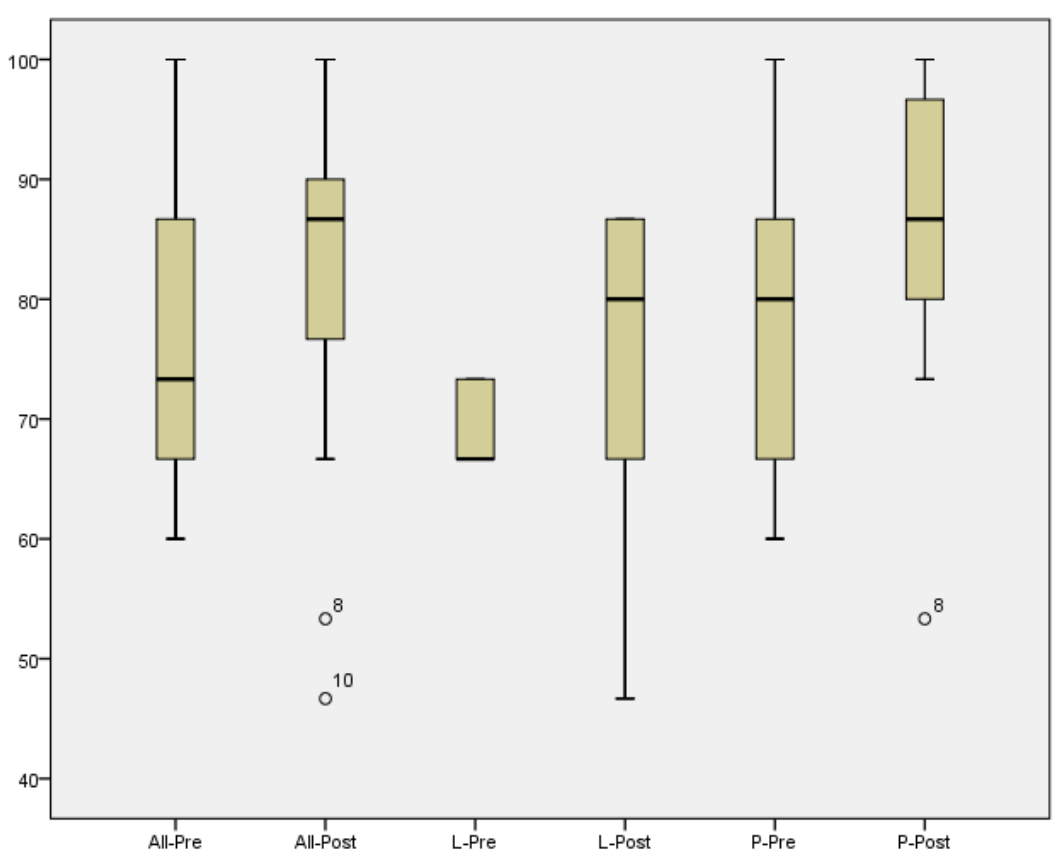

\section{Diagram Hasil Uji t Terhadap Hasil Pre-Post test IAIN Purwokerto}

Berdasarkan tabel olah statistic di atas, dapat diketahui bahwa:

1) Rata-rata nilai pre-test dan post-test seluruh peserta pelatihan literasi kitab IAIN Purwokerto menunjukan kenaikan. Nilai rata-rata post-test lebih tinggi (81.67) dibandingkan dengan nilai pre-test (75.42). Nilai rata-rata 
pre-test peserta perempuan lebih tinggi (78.18) daripada nilai rata-rata pre-test peserta laki-laki (69.33). Adapun setelah dilakukan pelatihan, rata-rata post-test peserta perempuan tetap lebih tinggi (85.45) daripada rata-rata nilai post-test peserta laki-laki (73.33).

2) Pengetahuan peserta literasi kitab IAIN Purwokerto secara umum mengalami kenaikan sebesar 6.25 poin. Peserta laki-laki mengalami kenaikan sebesar 4 poin, sedangkan peserta perempuan mengalami kenaikan sebesar 7.27 poin.

3) Dalam uji t menunjukkan bahwa secara keseluruhan peserta mengalami perubahan (positif) naik ada tingkat kecil yaitu dengan nilai t-test sebesar 0.11. Peserta laki-laki secara umum mengalami perubahan (positif) naik pada tingkat kecil yaitu dengan nilai t-test sebesar 0.66 dan peserta perempuan secara umum mengalami perubahan (positif) naik 0.11 lebih banyak mengalami perubahan dari pada peserta laki-laki.

4) Tingkat efektifitas pada pre-post test yang telah dilakukan menunjukkan bahwa secara keseluruhan peserta mengalami perubahan pada tingkat "kecil" dengan nilai efect size sebesar 0.42. Peserta laki-laki mengalami perubahan pada tingkat "kecil" yaitu dengan nilai efect size sebesar 0.21, sedangkan peserta perempuan mengalami tingkat perubahan pada tingkat "sedang" dengan nilai efect size sebesar 0.53 lebih besar dibanding laki-laki.

\section{Analisis Deskripsi Butir Soal Evaluasi Reaksi Peserta IAIN Salatiga}

a) IAIN Salatiga

Butir soal evaluasi reaksi peserta setelah mengikuti pelatihan literasi kitab menggunakan dua pendekatan yaitu pendekatan kuantitatif dan pendekatan kualitatif.

Analisis kuantitatif dilakukan dengan mengolah 10 butir pertanyaan yang terbagi dalam dua aspek yaitu spek relevansi (pada soal nomor 1,2,10) dan aspkek tingkat efektifitas pelatihan literasi kitab (pada soal nomor $3,4,5,6,7,8,9)$. Hasil dari jawaban peserta adalah sebagai berikut: 


\section{Tabel. 3 Reaksi Peserta Tehadap Literasi Kitab di IAIN Salatiga}

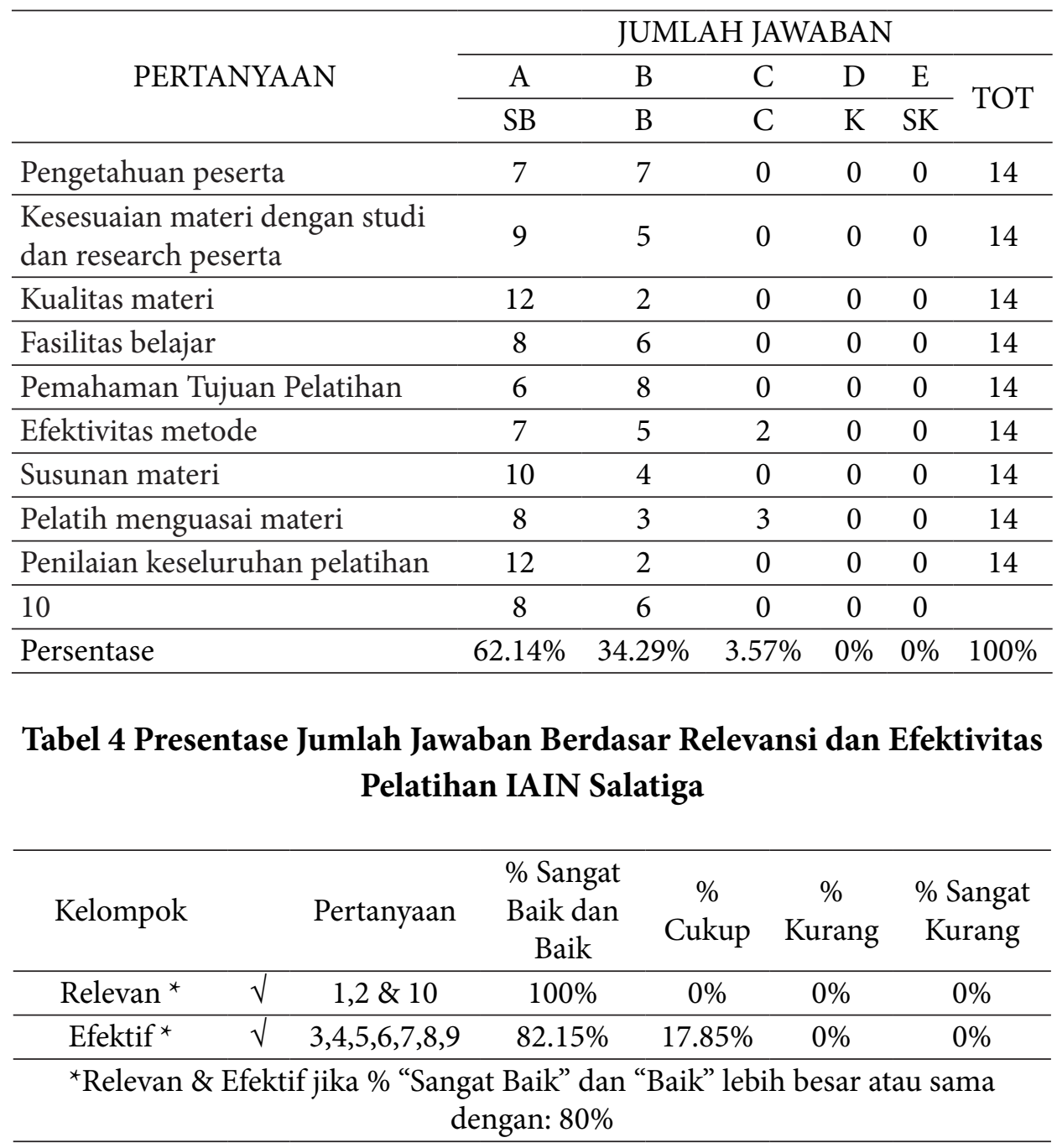

Berdasarkan tabel. 3 di atas, secara umum reaksi peserta terhadap pelatihan literasi kitab di IAIN Salatiga sangat bagus, yaitu peserta yang memberikan penilaian "sangat baik" sebesar $62.14 \%$, peserta yang memberikan penilai "baik" sebesar $34.29 \%$, dan peserta yang memberikan 
penilain "cukup" sebesar 3.57\%. Tidak ada peserta yang memberikan penilaian "kurang" maupun "sangat kurang".

Tabel. 4 di atas, menunjukkan tingkat relevansi dan efektifitas acara pelatihan literasi kitab di IAIN Salatiga. Adapun tingkat relevansi pelatihan literasi kitab sebesar $100 \%$. Kemudian untuk tingkat efektifitas pelatihan literasi kitab sebesar 82.15\%.

Dari penjelasan prosentase tingkat efektivitas dan relevansi pelatihan literasi kitab diatas. Dapat dilihat bahwa pelatihan literasi kitab sudah memenuhi standar relevansi dan efektifitas yang telah ditetapkan oleh peneliti yaitu lebih dari $80 \%$.

Tabel. 5 Reaksi Peserta Literasi Kitab IAIN Salatiga

\begin{tabular}{|c|c|c|}
\hline \multicolumn{3}{|c|}{ EVALUASI REAKSI PESERTA KUALITATIF IAIN SALATIGA } \\
\hline Pertanyaan & Reaksi Peserta & Jml \\
\hline \multirow{3}{*}{$\begin{array}{l}\text { 11. Apa yang anda sukai dari } \\
\text { pelatihan ini? }\end{array}$} & Mandapat ilmu yang bermanfaat & 8 \\
\hline & Metode penyampaian materi & 3 \\
\hline & Materi & 2 \\
\hline \multirow{5}{*}{$\begin{array}{l}\text { 12. Inovasi apa yang diperlukan } \\
\text { dalam pelatihan agar lebih baik? }\end{array}$} & Sudah Baik & 6 \\
\hline & Publikasi Acara & 1 \\
\hline & Peraturan & 3 \\
\hline & Praktik & 2 \\
\hline & Manajemen Waktu & 2 \\
\hline \multirow[t]{4}{*}{$\begin{array}{l}\text { 13. Apa yang anda lakukan setelah } \\
\text { mengikuti pelatihan? }\end{array}$} & $\begin{array}{l}\text { Memanfaat aplikasi yg sudah } \\
\text { dipelajari untuk kebutuhan riset } \\
\text { terkait dengan penelitian hadits }\end{array}$ & 11 \\
\hline & Mendalami lagi tentang hadis & 1 \\
\hline & Menginstal aplikasi yang dikaji & 1 \\
\hline & Mencoba memahami materi & 1 \\
\hline \multirow{3}{*}{$\begin{array}{l}\text { 14. Apakah ada kesulitan dalam } \\
\text { mengikuti pelatihan ini? }\end{array}$} & Tidak Ada & 8 \\
\hline & $\begin{array}{l}\text { Sedikit belum memahami materi } \\
\text { yang terakhir karena terlalu cepat } \\
\text { dan banyak }\end{array}$ & 3 \\
\hline & Jaringan Internet & 3 \\
\hline
\end{tabular}




\begin{tabular}{clc}
\hline \multicolumn{3}{c}{ EVALUASI REAKSI PESERTA KUALITATIF IAIN SALATIGA } \\
\hline Pertanyaan & \multicolumn{1}{c}{ Reaksi Peserta } & $\mathrm{Jml}$ \\
\hline $\begin{array}{l}\text { 15. Apakah anda memiliki pendapat } \\
\text { lain tentang pelatihan ini? }\end{array}$ & Tidak ada, sudah baik & 13 \\
\cline { 2 - 3 } & $\begin{array}{l}\text { Kalau pelatihannya diadakan } \\
\text { saat waktu seperti ini (sebelum }\end{array}$ & 1 \\
& $\begin{array}{l}\text { masuk kuliah) akan sangat } \\
\text { bermanfaat untuk mengisi waktu } \\
\end{array}$ & \\
& mahasiswa nya \\
\hline
\end{tabular}

Berdasarkan tabel.5 di atas dapat kita ketahui bahwa:

1) Peserta literasi kitab IAIN Salatiga menyukai acara pelatihan literasi kitab dalam aspek penambahan ilmu pengetahuan, metode penyampaian materi, dan substansi materi.

2) Peserta literasi kitab IAIN Salatiga kita memberikan apresiasi bahwa pelatihan sudah baik dan juga ada beberapa masukan terhadap pelaksanaan pelatihan literasi kitab, antara lain disediakan waktu lebih lama dalam pelatihan, memperbanyak praktik, pembuatan aturan yang lebih bagus, dan publikasi acara dilakukan jauh-jauh hari sebelum acara dilaksanakan.

3) Setelah mengikuti pelatihan literasi kitab peserta berencana memanfaatkan aplikasi yg sudah dipelajari untuk kebutuhan riset terkait dengan penelitian hadits, mendalami lagi tentang hadis, menginstal aplikasi yang dikaji, mencoba memahami materi.

4) Beberapa peserta ada yang tidak mengalami kesulitan dan ada yang mengalami kesulitan di akhir pelatihan literasi kitab dikarenakan terlalu banyak dan cepat materi yang disampaikan serta adanya kendala jaringan internet.

5) Peserta literasi kitab IAIN Salatiga memberikan pendapat bahwa pelatihan literasi kitab sudah baik dan sangat bermanfaat untuk mengisi waktu luang mahasiswa. 


\section{b) IAIN Purwokerto}

Butir soal evaluasi reaksi peserta setelah mengikuti pelatihan literasi kitab menggunakan dua pendekatan yaitu pendekatan kuantitatif dan pendekatan kualitatif.

Analisis kuantitatif dilakukan dengan mengolah 10 butir pertanyaan yang terbagi dalam dua aspek yaitu aspek relevansi (pada soal nomor 1,2,10) dan aspek tingkat efektifitas pelatihan literasi kitab (pada soal nomor $3,4,5,6,7,8,9)$. Hasil dari jawaban peserta adalah sebagai berikut:

\section{Tabel. 6 Reaksi Peserta Tehadap Literasi Kitab di IAIN Purwokerto}

\begin{tabular}{lcccccc}
\hline \multicolumn{1}{c}{ EVALUASI REAKSI PESERTA-KUANTITATIF IAIN PURWOKERTO } \\
\cline { 2 - 6 } & \multicolumn{6}{c}{ JUMLAH JAWABAN } \\
\cline { 2 - 6 } & $\begin{array}{c}\text { Sangat } \\
\text { Baik }\end{array}$ & B Baik & Cukup & Kurang & $\begin{array}{c}\text { Sangat } \\
\text { Kurang }\end{array}$ & TOTAL \\
\hline Pengetahuan peserta & 7 & 8 & 0 & 0 & 1 & 16 \\
\hline $\begin{array}{l}\text { Kesesuaian materi dengan } \\
\text { studi dan research peserta }\end{array}$ & 9 & 6 & 1 & 0 & 0 & 16 \\
\hline Kualitas materi & 10 & 5 & 1 & 0 & 0 & 16 \\
\hline Fasilitas belajar & 6 & 8 & 2 & 0 & 0 & 16 \\
\hline $\begin{array}{l}\text { Pemahaman Tujuan } \\
\text { Pelatihan }\end{array}$ & 7 & 8 & 1 & 0 & 0 & 16 \\
\hline Efektivitas metode & 5 & 10 & 1 & 0 & 0 & 16 \\
\hline Susunan materi & 10 & 5 & 1 & 0 & 0 & 16 \\
\hline Pelatih menguasai materi & 5 & 9 & 1 & 1 & 0 & 16 \\
\hline $\begin{array}{l}\text { Penilaian keseluruhan } \\
\text { pelatihan }\end{array}$ & 10 & 6 & 0 & 0 & 0 & 16 \\
\hline Pengetahuan peserta & 7 & 8 & 1 & 0 & 0 & 16 \\
\hline Persentase & $47.5 \%$ & $45.63 \%$ & $5.63 \%$ & $0.62 \%$ & $0,62 \%$ & $100 \%$ \\
\hline
\end{tabular}


Tabel. 7 Presentase Jumlah Jawaban Berdasar Relevansi dan Efektivitas Pelatihan IAIN Purwokerto

\begin{tabular}{ccccccc}
\hline Kelompok & Pertanyaan & $\begin{array}{c}\text { \% Sangat Baik } \\
\text { dan Baik }\end{array}$ & \% Cukup & $\begin{array}{c}\% \\
\text { Kurang }\end{array}$ & $\begin{array}{c}\text { \% Sangat } \\
\text { Kurang }\end{array}$ \\
\hline Relevan $^{*}$ & $\sqrt{ }$ & $1,2 \& 10$ & $93.75 \%$ & $4.17 \%$ & $0 \%$ & $2.08 \%$ \\
\hline Efektif $^{*}$ & $\sqrt{ }$ & $3,4,5,6,7,8,9$ & $92.85 \%$ & $5.35 \%$ & $0.9 \%$ & $0.9 \%$ \\
\hline${ }^{*}$ Relevan \& Efektif jika \% "Sangat Baik” dan “Baik” lebih besar atau sama \\
dengan: 80\%
\end{tabular}

Berdasarkan tabel. 6 di atas, secara umum reaksi peserta terhadap pelatihan literasi kitab di IAIN Purwokerto sangat bagus, yaitu peserta yang memberikan penilaian "sangat baik" sebesar $47.5 \%$, peserta yang memberikan penilai "baik" sebesar $45.63 \%$, peserta yang memberikan penilain "cukup" sebesar 5.63\%. peserta yang memberikan penilaian "kurang" sebesar $0.62 \%$, dan peserta yang memberikan penilain "sangat kurang" sebesar $0.62 \%$.

Berdasarkan tabel. 7 di atas, menunjukkan tingkat relevansi dan efektifitas acara pelatihan literasi kitab di IAIN Purwokerto. Adapun untuk tingkat relevansi pelatihan literasi kitab sebesar 93.75\%. Kemudian untuk tingkat efektifitas pelatihan literasi kitab sebesar $92.85 \%$.

Hal tersebut menunjukan bahwa pelatihan literasi kitab yang diadakan di perpustakaan IAIN Salatiga dan IAIN Purwokerto sudah memenuhi standar relevansi dan efektifitas yang telah ditetapkan oleh peneliti yaitu lebih dari $80 \%$. Dalam hal ini besarnya prosentase relevansi dan efektivitas pelatihan berdampak besarnya kontribusi dalam mencapai tujuan.

\section{Tabel. 8 Reaksi Peserta Literasi Kitab IAIN Purwokerto}

EVALUASI REAKSI PESERTA KUALITATIF IAIN PURWOKERTO

\begin{tabular}{ccc}
\hline Pertanyaan & Reaksi Peserta & Jumlah \\
\hline $\begin{array}{l}\text { 11. Apa yang anda sukai dari } \\
\text { pelatihan ini? }\end{array}$ & Mandapat ilmu yang Bermanfaat & 5 \\
\hline
\end{tabular}




\begin{tabular}{|c|c|c|}
\hline \multicolumn{3}{|c|}{ EVALUASI REAKSI PESERTA KUALITATIF IAIN PURWOKERTO } \\
\hline \multirow[t]{4}{*}{ Pertanyaan } & Reaksi Peserta & Jumlah \\
\hline & Metode Penyampaian Materi & 3 \\
\hline & Materi & 4 \\
\hline & Praktek & 4 \\
\hline \multirow{7}{*}{$\begin{array}{l}\text { 12. Inovasi apa yang perlu } \\
\text { dilakukan agar pelatihan ini } \\
\text { menjadi lebih baik? }\end{array}$} & Praktek Langsung & 3 \\
\hline & Sudah Baik & 2 \\
\hline & Perbaikan Jaringan & 3 \\
\hline & Sosialisasi Acara Lebih Luas & 2 \\
\hline & $\begin{array}{l}\text { Pengembangan Fitur Bookless agar } \\
\text { lebih lengkap dan mudah diakses }\end{array}$ & 4 \\
\hline & $\begin{array}{l}\text { Alangkah lebih baiknya agar } \\
\text { pemateri tidak hanya satu. }\end{array}$ & 1 \\
\hline & Ada hadiah yang menariknya & 1 \\
\hline \multirow{4}{*}{$\begin{array}{l}\text { 13. Apa yang anda lakukan } \\
\text { setelah mengikuti pelatihan } \\
\text { ini? }\end{array}$} & $\begin{array}{l}\text { Mempraktekan Materi yang sudah } \\
\text { didapat }\end{array}$ & 6 \\
\hline & Mengakses Bookless & 7 \\
\hline & $\begin{array}{l}\text { mencari informasi lebih lanjut } \\
\text { tentang bookless }\end{array}$ & 2 \\
\hline & berinnovasi dengan bookless & 1 \\
\hline \multirow{2}{*}{$\begin{array}{l}\text { 14.. Apakah ada kesulitan dalam } \\
\text { mengikuti pelatihan ini? }\end{array}$} & Tidak Ada Kesulitan & 8 \\
\hline & Kendala Jaringan & 8 \\
\hline \multirow{4}{*}{$\begin{array}{l}\text { 15. Apakah anda memiliki } \\
\text { pendapat/saran lain tentang } \\
\text { pelatihan ini? }\end{array}$} & Tidak ada, sudah baik & 8 \\
\hline & $\begin{array}{l}\text { Mengadakan pelatihan rutin } \\
\text { dengan tema lain dan peserta lebih } \\
\text { luas }\end{array}$ & 5 \\
\hline & efisiensi waktu oleh narasumber & 1 \\
\hline & $\begin{array}{l}\text { penambahan narasumber lebih dari } \\
\text { satu }\end{array}$ & 1 \\
\hline
\end{tabular}

Berdasarkan tabel.8 di atas dapat kita ketahui bahwa:

1) Peserta literasi kitab IAIN Purwokerto menyukai acara pelatihan literasi kitab dalam aspek penambahan ilmu pengetahuan, metode penyampaian materi, materi, dan durasi praktik diperpanjang selama pelatihan. 
2) Peserta literasi kitab IAIN Purwokerto ada yang menyampaikan bahwa pelatihan yang diberikan sudah baik, ada yang memberikan beberapa masukan terhadap pelaksanaan pelatihan literasi kitab, antara lain praktik langsung aplikasi Bookless, perbaikan jaringan internet, sosialisasi acara yang lebih luas, pengembangan fitur bookless agar lebih lengkap dan mudah diakses, penambahan jumlah narasumber dan tersedianya hadiah yang menarik.

3) Setelah mengikuti pelatihan literasi kitab peserta berencana mempraktekan materi yang sudah didapat, mengakses Bookless, mencari informasi lebih lanjut tentang bookless, dan berinovasi dengan bookless.

4) Peserta literasi kitab IAIN Purwokerto secara umum tidak mengalami kesulitan dalam pelatihan, hanya saja sebagian peserta mengalami kendala pada jaringan internet.

5) Peserta literasi kitab IAIN Purwokerto memberikan beberapa pendapat diantaranya pelatihan sudah baik, pelatihan literasi kitab perlu diadakan secara rutin, mengundang peserta lebih banyak, efisiensi waktu narasumber dan penambahan jumlah narasumber.

\section{Tingkat Efektivitas Penyelenggaraan Pelatihan Literasi Kitab di IAIN Salatiga dan IAIN Purwokerto}

Berdasarkan olah data pre-test dan post-test pengetahuan peserta literasi kitab IAIN Salatiga secara umum mengalami penurunan sebesar -9.05 poin, peserta laki-laki mengalami penurunan sebesar -10 poin, sedangkan peserta perempuan mengalami penurunan sebesar -8.66 poin.

Tingkat efektifitas pada pre-post test yang telah dilakukan memberikan dampak perubahan menurun tingkat "sedang" dengan nilai efect size sebesar -0.52 .

Peserta laki-laki mengalami perubahan menurun tingkat "sedang" dengan nilai efect size - 0.78 lebih besar dibandingkan dengan nilai efect size peserta perempuan sebesar -0.45 .

Berdasarkan tabel. 4, menunjukkan tingkat relevansi dan efektifitas acara pelatihan literasi kitab di IAIN Salatiga. Adapun untuk tingkat relevansi 
pelatihan literasi kitab sebesar $100 \%$. Kemudian untuk tingkat efektifitas pelatihan literasi kitab sebesar $82.15 \%$. Hal tersebut menunjukan bahwa pelatihan literasi kitab sudah memenuhi standar relevansi dan efektifitas yang telah ditetapkan oleh peneliti yaitu lebih dari $80 \%$.

Adapun Pengetahuan peserta literasi kitab IAIN Purwokerto secara umum mengalami kenaikan sebesar 6.25 poin. Peserta laki-laki mengalami kenaikan sebesar 4 poin, sedangkan peserta perempuan mengalami kenaikan sebesar 7.27 poin.

Tingkat efektifitas pada pre-post test yang telah dilakukan menunjukkan bahwa secara keseluruhan peserta mengalami perubahan pada tingkat "kecil" dengan nilai efect size sebesar 0.42. Peserta laki-laki mengalami perubahan pada tingkat "kecil" yaitu dengan nilai efect size sebesar 0.21 , sedangkan peserta perempuan mengalami tingkat perubahan pada tingkat "sedang" dengan nilai efect size sebesar 0.53 lebih besar dibanding laki-laki.

Dan berdasarkan tabel. 7, pelatihan literasi kitab di IAIN Purwokerto menunjukkan tingkat relevansi dan efektifitas acara pelatihan literasi kitab di IAIN Purwokerto. Adapun untuk tingkat relevansi pelatihan literasi kitab sebesar $93.75 \%$. Kemudian untuk tingkat efektifitas pelatihan literasi kitab sebesar 92.85\%. Hal tersebut menunjukan bahwa pelatihan literasi kitab sudah memenuhi standar relevansi dan efektifitas yang telah ditetapkan oleh peneliti yaitu lebih dari $80 \%$.

\section{Jenis-Jenis Pengetahuan dan Skill Literasi Kitab yang dibutuhkan Mahasiswa IAIN Salatiga dan IAIN Purwokerto}

Jenis-jenis pengetahuan dan skill liteasi kitab yang dibutuhkan mahasiswa IAIN Salatiga adalah penelusuran kitab-kitab fiqh, ushul fiqh, ulumul qur'an, asbabun nuzul, tafsir, penelusuran kitab-kitab hadis, penelusuran sanad / perawi hadis, penelusuran tingkatan hadis, istilah dasar Ilmu Hadis (hadis sahih, hadis hasan, hadis daif, hadis berdasarkan beritanya); implikasi hukum dari hadis (hadis sahih yang tidak bisa diamalkan, hadis daif yang bisa diamalkan, hadis yang wajib diamalkan); ketersambungan sanad (Indikator sanad yang tersambung, sanad yang seolah tersambung namun 
sebenarnya terputus); indikator jarh wa ta'dil (pernyataan penilaian adil dan pernyataan penilaian dabit); dan pratek penilaian hadis (takhrij, i'tibar). Dan berbagai pengetahuan dan skill penelusuran dan penggunaan kitab referensi Islam yang tersedia di Perpustakaan IAIN Salatiga.

Kemudian untuk mahasiswa IAIN Purwokerto jenis-jenis pengetahuan dan skill literasi kitab yang dibutuhkan dalam pemanfaatan bookles adalah sumber informasi kitab digital (sosialisasi bookless, definisi bookless, cara penggunaan bookless, sistem informasi di bookless); efektifitas bookless library (kemudahan akses bookless, penelusuran qur'an, hadis, fiqih, pengetahuan sejarah, penelusuran buku-buku digital); pengorganisasian informasi (penggunaan hasil penelusuran untuk sumber kutipan dan validasi informasi); orientasi pengembangan sistem (pemanfaatan bookless sebagai literasi kitab digital, pemanfaatan bookless sebagai penunjang studi dan penelitian, pengembangan pengetahuan dan wawasan). Dan berbagai pengetahuan dan skill penelusuran dan penggunaan kitab referensi Islam yang tersedia di Perpustakaan IAIN Purwokerto.

\section{Peningkatan Kemampuan Mahasiswa dan Penguasaan Skill Literasi Kitab Mahasiswa IH FUAH IAIN Salatiga}

Peneliti juga meminta usulan dari para peserta pelatihan literasi kitab agar ke depan acara pelatihan literasi kitab bisa dilakukan dengan lebih maksimal. Usulan dari peserta dari FUAH IAIN Salatiga antara lain dari beberapa aspek yaitu

1. Pengembangan Materi Pelatihan

2. Memperbaiki Metode Pelatih dalam menyampaikan materi

3. Memperpanjang waktu publikasi/sosialisasi pelatihan

4. Penambahan Penambahan waktu praktek

5. Manajemen waktu pelatihan

6. Dan menyediakan teknologi media pelatihan yang representatif dan jaringan internet yang memadai.

7. Memperbaiki aturan mengikuti pelatihan 
Adapun usulan dari pesera mahasiswa FUAH IAIN Purwokerto terkait pelatihan literasi kitab yaitu

1. Pengembangan Materi Pelatihan

2. Memperbaiki Metode Pelatih dalam menyampaikan materi

3. Memperpanjang waktu publikasi/sosialisasi pelatihan

4. Penambahan Penambahan waktu praktek

5. Manajemen waktu pelatihan

6. Dan menyediakan teknologi media pelatihan yang representatif dan jaringan internet yang memadai.

7. Penambahan pemateri/narasumber

8. Menyediakan hadiah menarik untuk peserta pelatihan.

9. Pengembangan fitur bookless agar lebih lengkap dan mudah diakses

\section{E. KESIMPULAN}

1. Tingkat efektivitas pelatihan literasi kitab bagi mahasiswa FUAH IAIN Salatiga sebesar $82.15 \%$ dan IAIN Purwokerto sebesar 92.85\%. hal ini menunjukkan bahwa pelatihan literasi kitab yang diselenggarakan oleh Perpustakaan IAIN Salatiga dan IAIN Purwokerto telah berjalan sangat efektif dengan hasil prosentase "sangat baik" dan "baik" lebih besar atau sama dengan $80 \%$. Hal ini berarti hasil pelatihan tersebut berkontribusi terhadap tujuan pelatihan literasi kitab. Namun demikian pelatihan literasi kitab ini masih perlu dikembangkan dan dilakukan secara berkelanjutan ditahun-tahun mendatang.

2. Jenis-jenis pengetahuan dan skillyang dibutuhkan mahasiswa FUAH IAIN Salatiga adalah penelusuran kitab-kitab tafsir, penelusuran kitab-kitab hadis, penelusuran sanad / perawi hadis, penelusuran tingkatan hadis, istilah dasar Ilmu Hadis, implikasi hukum dari hadis, ketersambungan sanad, indikator jarh wa ta'dil, pratek penilaian hadis. Serta berbagai pengetahuan dan skill penelusuran/penggunaan kitab referensi Islam yang tersedia di Perpustakaan IAIN Salatiga sebagai penunjang studi dan penelitian mahasiswa. Adapun jenis-jenis pengetahuan dan skill yang 
dibutuhkan mahasiswa FUAH IAIN Purwokerto dalam pemanfaatan bookles sebagai sumber informasi kitab digital, efektifitas penggunaan bookless library, pengorganisasian informasi, orientasi pengembangan sistem bookless. Serta berbagai pengetahuan dan skill penelusuran/ penggunaan kitab referensi Islam yang tersedia di Perpustakaan IAIN Purwokerto sebagai penunjang studi dan penelitian mahasiswa.

3. Upaya Peningkatan kemampuan mahasiswa dalam penguasaan skill literasi kitab baik di IAIN Salatiga dan IAIN Purwokerto yaitu melalui pendekatan berupa: pengembangan materi pelatihan, memperbaiki model pelatih dalam menyampaikan materi, memperpanjang waktu publikasi/ sosialisasi pelatihan, penambahan waktu praktek, manajemen waktu pelatihan yang baik, menyediakan teknologi media pelatihan yang representatif dan jaringan internet yang memadai, dan pengembangan sistem informasi kitab digital.

\section{DAFTAR PUSTAKA}

Abdin, Y. (2018). Pembelajaran Literasi. Jakarta: Bumi Aksara

Amstrong, C. et.al. 2005. Defining Information Literacy for the UK. http:// eprints.rclis.org/7459/

Indah Wijaya Antsari. (2017). Analisis Promosi Layanan Bookless di Perpustakaan Institut Agama Islam Negeri Purwokerto, Pustakaloka Jurnal Kajian Informsi dan Perpustakaan, Perpustakaan IAIN Ponorogo. Vol. 9 No. 2.

http://jurnal.iainponorogo.ac.id/index.php/pustakaloka/article/view/1088 (2017). Persepsi Pemustaka Terhadap Layanan Bookless di Perpustakaan IAIN Purwokerto, Tik Ilmeu: Jurnal Ilmu Perpustakaan dan Informasi, Perpustakaan STAIN Curup. Vol. 1 No. 1.

http://journal.iaincurup.ac.id/index.php/TI/article/view/208

Badan Standardisasi Nasional. (2009). Standar Nasional Indonesia Perpustakaan Perguruan Tinggi 7330:2009. Jakarta. 
http://perpustakaan.kemenkopmk.go.id/perpus/assets/kitchen/berkas/ ebook/standar_nasional_indonesia_bidang_kepustakaan_dan_ kepustakawanan1.pdf

Nurhadi, Mulyani A. Sejarah Perpustakaan Dan Perkembangannya Di Indonesia.

Yogyakarta: Andi Offset, 1983.

Dian Maisaroh, (2020). Literasi Kitab Kuning Pada Santri Pondok Pesantren Al-Muhsinin Desa Koto Petai Kabupaten Kerinci. Skripsi FUAH, UIN Sulthan Thaha Saifuddin Jambi. http://repository.uinjambi.ac.id/3970/

Dirjen Pendis RI. (2020). Surat Edaran Direktur Pendidikan Islam No. 697/03/2020 Tahun 2020 Tentang Perubahan Atas Surat Edaran Direktur Jenderal Pendidikan Islam Nomor 657/03/2020 Tentang Upaya Pencegahan Penyebaran Covid-19 (Corona) di Lingkungan Perguruan Tinggi Keagamaan Islam.

http://itjen.kemenag.go.id/sirandang/peraturan/5919-697032020perubahan-atas-surat-edaran-direktur-jenderal-pendidikan-islamnomor-657032020-tentan

Djarwanto. (1994). Pokok-pokok Metode Riset dan Bimbingan Teknis Penulisan. Skripsi. Yogyakarta: Liberty.

http://repository.uin-suska.ac.id/4127/8/em.pdf

Hartono, B. (2016). Manajemen Perpustakaan Sekolah. Yogyakarta: Ar-Ruzz Media.

Hendra Wicaksono dkk, (2016). Analisis Keterampilan Literasi Informasi Pustakawan Pusat Informasi Ilmiah di Lingkungan Universitas Jenderal Soedirman Purwokerto Berdasarkan Model The Big 6. Lentera Pustaka 2 (I): $21-44,44$.

https://scholar.google.co.id/scholar?hl=en\&as_sdt=0\%2C5\&as_vis=1\&q=T he+big+6+kebutuhan+literasi\&btnG=

Rachman Hermawan dan Zulfikar Zein. (2006). Etika Kepustakawanan: Suatu Pendekatan Terhadap Kode Etik Pustakawan Indonesia. Jakarta: Sagung Seto. 
http://darunnajah.ac.id/tiga-tugas-besar-ptkin-ptkis-di-indonesia/ http://diktis.kemenag.go.id

https://www.statistikian.com/2012/10/pengertian-populasi-dan-sampel.html IAIN Salatiga. (2019). Buku Pedoman: Layanan Perpustakaan.Salatiga: UPT Perpustakaan IAIN Salatiga.

IAIN Purwokerto. (2020). Buku Pedoman: Layanan Perpustakaan. Salatiga: UPT Perpustakaan IAIN Purwokerto.

Ikbar Junakarta, dkk. (2018). Makalah Kriteria dan Teknik Pemeriksaan Keabsahan Data, Jurusan PAI, FTIK IAIN Pontianak.

http://www.merekamgagas.web.id/2018/11/makalah-kriteria-dan-teknikpemeriksaan.html

Urias Ibo. (2008) Pengembangan Koleksi Di UPT Perpustakaan Universitas Cendrawasih Papua. Bandung: FIKOM Universitas Padjajaran.

Kemenag RI. (2020). Surat Edaran Nomor SE. 5 Tahun 2020 Tentang Penyesuaian Sistem Kerja Pegawai Dalam Upaya Pencegahan Penyebaran Corona Virus Disease 2019 (Covid-19) pada Kementerian Agama. http://itjen.kemenag.go.id/sirandang/peraturan/5906-2penyesuaian-sistem-kerja-pegawai-dalam-upaya-pencegahanpenyebaran-corona-virus-disease-2019-

Kirkpatrick, D.L. \& Kirkpatrick, J.D. (2007). Implementing the Four Levels: a Pratical Guide for Effective Evaluation of Training Programs $\left(1^{\text {st }} \mathrm{ed}\right)$. San Francisco: Berrett-Koehler Publisher.

Lalu Agus Satriawan, dkk. (2015). Pemetaan dan Analisis Kebutuhan Koleksi Referensi Perpustakaan IAIN Mataram. Libraria, 4 (2015). ISSN 20887310 http://repository.uinmataram.ac.id/246/

Mahmudi. (2005). Manajemen Kinerja Sektor Publik ( $1^{\text {st }}$ ed.). Yogyakarta: UPP AMP YKPN.

I. Malawy, (2017). Pembelajaran Literasi Berbasis Sastra Lokal. Jawa Timur: Media Grafika.

Mufid dan Ari Zuntriana. (2016). Efektivitas Pelatihan ORS (Online Research Skills) untuk Mendukung Studi dan Penelitian Mahasiswa di UIN 
Maulana Malik Ibrahim Malang, Al-Maktabah, Vol. 15 No. 1-10. Mulyani A. Nurhadi. (1983). Sejarah Perpustakaan Dan Perkembangannya Di Indonesia. Yogyakarta: Andi Offset.

Soeatminah. (1992). Perpustakaan, Kepustakawan dan Pustakawan, cet 1, Yogyakarta: Karnisius.

Sugiyono. (2017). Metode Penelitian Kuantitatif, Kualitatif, dan R\&D. Bandung: Alfabeta, CV.

Sulistyo Basuki. (1993). Pengantar Ilmu Perpustakaan, Jakarta: Gramedia Pustaka Utama.

Nurhadi, Mulyani A. Sejarah Perpustakaan Dan Perkembangannya Di Indonesia.

Yogyakarta: Andi Offset, 1983.

Widjajanta, B. (2015). Efektivitas Penerapan Program Literasi Informasi di Perpustakaan Universitas Atma Jaya Yogyakarta: Studi tentang Penerapan Program Association of College \& Research Libraries di Perpustakaan Universitas Atmajaya Yogyakarta, Universitas Wijaya Kusuma Surabaya. http://e-journal.uajy.ac.id/7559/1/Skripsi0.pdf

Wiji Suwarno. (2016). Organisasi Informasi Perpustakaan: Pendekatan Teori Dan Praktik. Jakarta: Rajawali Press.

.(2016). Library Life Style (Trend dan Ide Kepustakawanan. Jogyakarta: Lembaga Ladang Kata. .(2010). Ilmu Perpustakaan \& Kode Etik Pustakawan. Jogyakarta: Ar-Ruzz Media.

Winata, A.P. \& Djunaidi, A. (2005). Efektivitas Pelatihan Literasi Informasi. Universitas Gadjah Mada, Yogyakarta.

http://etd.repository.ugm.ac.id/index.php?mod=penelitian_detail\&sub=Pe nelitianDetail\&act=view\&typ=html\&buku_id=84464\&obyek_id=4 
Ifonilla Yenianti 